\title{
CONTROLE INTERNO MOSTRA SUA FORÇA NO COMBATE À CORRUPÇÃO
}

Coluna publicada em 19.11.2013:<http://www.conjur.com.br/2013-nov-19/ contas-vista-controle-interno-mostra-forca-combate-corrupcao $>$

Nas últimas semanas o noticiário ocupou-se com as denúncias de corrupção envolvendo servidores da administração pública do Município de São Paulo. O desvio de recursos públicos causado pela corrupção é um mal que parece difícil, se não impossível, de extirpar. ${ }^{1}$ Mas há que se trabalhar sempre tendo como meta a sua erradicação total. Trata-se de tema de grande interesse do Direito Financeiro, mas não pretendo abordá-lo nesta coluna, o que certamente será feito em outra oportunidade. Pretendo, neste texto, chamar a atenção e destacar o trabalho de um órgão ainda muito pouco conhecido, mas que foi o responsável por dar início e realizar as investigações que trouxeram a público a existência destes lamentáveis acontecimentos: o controle interno.

A intensa atividade financeira do Estado envolve imensas quantias de dinheiro, que cada um de nós entrega ao Poder Público para delas fazer bom uso, retornando à sociedade em forma de obras, serviços, enfim, ações governamentais que atendam as necessidades públicas. Apropriar-se desses recursos, como se vê nesses e em outros escândalos que envolvem atos de corrupção, como os ora mencionados, é fato que se sabe ocorrer com indesejada frequência, cabendo ao Estado saber prevenir e combater.

Para isso, são fundamentais os sistemas e órgãos que atuam nesse sentido, e são muitos. Enumerar todos certamente importará em omissões, mas vê-se destacarem o Poder Judiciário, Ministério Público, Procuradorias e muitas organizações governamentais e não governamentais.

1 Verdadeira violência aos direitos humanos, como ressalta Regis de Oliveira (Curso de direito financeiro, São Paulo, RT, 2013, p. 311). 
No âmbito do Direito Financeiro, nossa Constituição prevê um bem organizado sistema de fiscalização da atividade financeira do setor público, que é fundamental para evitar e combater não somente a corrupção, mas toda e qualquer forma de desvio e malversação de recursos públicos.

O artigo 70 da Constituição estabelece que essa fiscalização é exercida de duas formas: pelos sistemas de controle externo e de controle interno. O controle externo é exercido pelo Poder Legislativo, com o auxílio dos Tribunais de Contas; o controle interno, pelos órgãos de controle interno presentes no âmbito de cada um dos poderes, em todas as unidades da federação. ${ }^{2}$ Os Tribunais de Contas e os órgãos de controle interno têm papel fundamental nas ações de fiscalização das contas públicas. E, curiosamente, são pouco conhecidos, o que é de se lamentar, pela relevância das suas atribuições.

No caso da Prefeitura de São Paulo, sobressaiu a atuação do controle interno, motivo pelo qual dedicarei esta coluna a tecer algumas considerações, ainda que de forma sucinta, sobre esse órgão tão importante. Mas não me esquecerei dos Tribunais de Contas, sobre os quais falarei em muitas outras oportunidades.

O controle interno tem, atualmente, suas atribuiçōes delineadas no artigo 74 da Constituição, em que está previsto que cada um dos poderes deverá manter sistema de controle interno, com as finalidades descritas nos incisos I a IV, destacando-se a avaliação do cumprimento das metas previstas nas leis orçamentárias, comprovar a legalidade dos atos relacionados à gestão pública, avaliar a qualidade do gasto público e dar apoio ao sistema de controle externo.

Inicialmente, o controle interno era exercido pelo Poder Executivo, aperfeiçoando-se sua estrutura após a Constituição de 1988, quando passou a ser exigido no âmbito de cada um dos poderes, em respeito à autonomia e separação de poderes. Constata-se também que, em sua origem, exercia uma avaliação meramente formal da atividade financeira do Estado, baseada na legalidade e regularidade documental dos atos de despesa pública.

Essa forma de atuação não se mostra mais compatível com a modernização da administração pública, hoje com suas preocupações voltadas ao planejamento e à qualidade do gasto público, que não prescinde de um sistema de controle adequado a esses novos tempos. A Constituição de 1988 andou bem em estabelecer esse novo sistema de controle interno, com uma atuação que tenha por foco não a forma, mas sim a finalidade do gasto público.

2 Exceção feita aos municípios em que há um único órgão de controle interno para os Poderes Executivo e Legislativo (CF, art. 31). 
Vê-se que a administração pública tem sido lenta ao cumprir o que foi estabelecido pela Constituição, sendo, muitas vezes, recente a estruturação dos órgãos de controle interno e adaptação de suas rotinas às novas funções. Não obstante essa demora, o importante é que se observa um avanço nos órgãos de controle interno, que têm se modernizado com vistas a cumprir bem a missão que lhes foi confiada.

Muitos Municípios e estados, e os Poderes Legislativo e Judiciário, demoraram a instituir seus órgãos de controle interno. No âmbito do Poder Judiciário, a maior parte dos Tribunais somente os implantou a partir de 2009, em função da determinação constante da Resolução 70/2009 do Conselho Nacional de Justiça.

No Município de São Paulo, o órgão de controle interno encontra-se junto à Controladoria Geral do Município, que tem atribuiçôes mais amplas, exercendo, além das funções próprias do controle interno, as de defesa do patrimônio público, auditoria pública, prevenção e combate à corrupção, ouvidoria, promoção da ética no serviço público, o incremento da moralidade e da transparência e o fomento do controle social da gestão, entre outras (Lei Municipal 15.764, de 2013, arts. 118 e seguintes). Segue modelo semelhante a outros entes da federação, como a União, em que o principal órgão é a Secretaria Federal de Controle Interno, que integra a Controladoria Geral da União (CGU), que também tem se destacado no combate ao desvio de recursos públicos.

As tarefas do controle interno exigem que o órgão seja dotado de autonomia, o que lhe deve ser assegurado, a fim de que possa ter liberdade de ação e apurar irregularidades, como as recentemente noticiadas. Daí porque precisa estar subordinado tão somente ao dirigente máximo do órgão, ${ }^{3}$ a quem deve se reportar diretamente.

Além dessas ações que foram noticiadas, que permitiram nesta e em outras vezes identificar atos de corrupção, é importante destacar que o controle interno é mais do que um órgão fiscalizador, que apura irregularidades, a fim de que sejam tomadas as medidas punitivas com relação aos responsáveis pelos atos, e indique as demais providências voltadas a corrigir as falhas que permitiram a ocorrência dos desvios. Trata-se de órgão que tem importantes funções de assessoramento para toda a administração pública.

Um prefeito, governador ou presidente de ente da federação, do Poder Legislativo, ou mesmo de um Tribunal do Poder Judiciário, e tantos outros órgãos da administração pública, são responsáveis por gerenciar, por vezes, bilhões de reais, e não são

Tribunal de Contas da União, Acórdão 1.074, rel. Min. Weder de Oliveira, publicado DOU de 22 de maio de 2009. 
necessariamente especialistas em gestão pública. Precisam de um órgão em que possam confiar que lhes dê apoio e orientação técnica para serem bons gestores.

Por isso, o controle interno deve cada vez mais evoluir no sentido de atuar com base na prevenção, orientação e correção dos atos de gestão. ${ }^{4}$

A Constituição mostra o caminho, no já citado artigo 74 , deixando claras as finalidades do sistema de controle interno no que tange à qualidade do gasto público, avaliando os resultados, quanto à eficácia e eficiência, da gestão orçamentária, financeira e patrimonial da administração pública (CF, art. 74, II) e no que se refere à responsabilidade na gestão fiscal, acompanhando as metas de planejamento governamental e execução dos programas de governo (CF, art. 74, I), bem como fiscalizando as normas da Lei de Responsabilidade Fiscal (Lei Complementar 101, de 2000, art. 59). Cabe aos órgãos de controle interno continuar avançando, tendo em vista o papel fundamental que estão desempenhando para melhorar a administração pública.

Melhorar a gestão dos recursos públicos, exigindo que os governantes apliquem correta e adequadamente o dinheiro público, é interesse de todos e nossa obrigação. E a luta contra a corrupção deve ser permanente. Todos nós podemos colaborar com isso. É bom lembrar que qualquer cidadão, partido político, associação ou sindicato é parte legítima para denunciar irregularidades ou ilegalidades $\left(\mathrm{CF}\right.$, art. $\left.74, \$ 2^{\circ}\right)$. O cidadão é, sem dúvida, o melhor fiscal da aplicação dos recursos públicos. Façamos a nossa parte, o controle interno e os demais órgãos de fiscalização agradecem!

4 Como já escrevemos em: CONTI, José Mauricio; CARVALHO, André Castro. O controle interno na Administração Pública brasileira: qualidade do gasto público e responsabilidade fiscal. $D i$ reito público, ano VIII, n. 37, jan./fev. 2011, Porto-Alegre-Brasília: Síntese-IDP, p. 203. 